\title{
Gambaran Terapi Diabetes Melitus Tipe 2 dengan Komorbid Hipertensi di Rumah Sakit X Pekanbaru
}

\author{
Inayah $^{1 *}$, M.Yulis Hamidy ${ }^{1}$, Mayang Sari ${ }^{2}$
}

\begin{abstract}
The contribution of hypertension to diabetes, as the leading cause of death, is very important. Thus, aggressive management in diabetes mellitus patients comorbid with hypertension is thouroghly required. The purpose of the descriptive study is to describe the treatment of cormobide type 2 diabetes mellitus and hypertension. Data were retrieved from the medical records of patients' X hospital in Pekanbaru through period January - December 2014. There were 285 subjects. The average of age and random blood glucose level are $57.73( \pm 9.95)$ and $260.67( \pm$ $126.93) \mathrm{mg} / \mathrm{dL}$, consecutively. The systolic blood pressure of e"160 $\mathrm{mmHg}(38.9 \%)$ and diastolic blood pressure of $80-89 \mathrm{mmHg}(40,7 \%)$ are moslty found in this study. Oral Anti-Diabetic Drugs (ADD) are administered to $83.15 \%$ of the subjects, while $3.5 \%$ of the subjects are given insulin. The most frequent oral ADD administerd is the combinaton of two drugs (49.47\%), of Metformin group (90.3\%) with daily dose 1000-1500 mg (74.26\%). The most common Anti Hypertension Drugs used is angiotensin receptor blocker $75.8 \%$ (candesartan $66.24 \%$ \& valsartan $9.55 \%$ ). The conclusion is metformin and candesartan were the most common drugs used in the treatment of diabetes mellitus comorbid with hypertension.
\end{abstract}

Keywords: anti-diabetic drugs, diabetes mellitus type 2, anti-hypertension drugs, Hypertension

2. FK URDiabetes melitus dikenal sebagai "mother of disease" yang merupakan induk dari berbagai penyakit seperti hipertensi, penyakit jantung, stroke, gagal ginjal dan kebutaan. ${ }^{1}$ International Diabetes Federation (IDF) menyatakan lebih dari 371 juta orang di dunia yang berumur 20-79 tahun menderita penyakit diabetes dan akan terus meningkat. Indonesia merupakan negara urutan ke-7 dunia dengan prevalensi diabetes tertinggi setelah Tiongkok, India, Amerika Serikat, Brazil, Rusia dan Meksiko. ${ }^{2}$

Hipertensi adalah penyakit yang biasanya berdampingan dengan DM yang dapat memperburuk komplikasi DM dan morbiditas kardiovaskular. Diperkirakan 3 juta orang Amerika menderita diabetes dengan hipertensi. Kontribusi hipertensi terhadap penyakit DM sebagai penyebab kematian utama sangat besar, terlihat bahwa hipertensi telah terlibat sebanyak $4,4 \%$ dalam kematian pada pasien DM. Begitu juga sebaliknya,

\footnotetext{
* Penulis untuk korespondensi:

KJF Farmakologi FK UR, email: umiadya@yahoo.com
}

DM terlibat sebanyak $10 \%$ dalam kematian pada pasien penyakit hipertensi. Hal ini yang melatarbelakangi perlunya manajemen yang agresif pada pasien DM yang disertai dengan hipertensi untuk mencegah dan memghambat progresifitas dan komplikasi penyakit. ${ }^{3,4}$,

Hipertensi merupakan salah satu penyulit dalam pengelolaan pasien DM tipe 2. Pengobatan hipertensi pada DM tipe 2 diindikasikan jika sistolik $>130 \mathrm{mmHg}$ dan atau diastolik >80 mmHg. Pada terapi farmakologis pasien hipertensi dengan diabetes selain diberikan obat anti diabetik (OAD) juga ditambahkan obat anti hipertensi (OAH) dengan memperhatikan beberapa hal, seperti pengaruh $\mathrm{OAH}$ terhadap profil lipid, metabolisme glukosa, resistensi insulin, dan hipoglikemia terselubung. ${ }^{5}$ Obat anti hipertensi lini pertama pada pasien tersebut adalah diuretik thiazid, penghambat Angiotensin-Converting Enzyme (ACE-Inhibitor), antagonis reseptor angiotensin II (Angiotensin receptor blocker, $A R B$ ), dan antagonis kalsium. ${ }^{6}$

Masih terbatasnya penelitian tentang gambaran terapi pada pasien DM tipe 2 dengan komorbid 
hipertensi di rumah sakit Pekanbaru sehingga peneliti tertarik untuk melakukan penelitian ini. Penelitian ini bertujuan untuk mengetahui gambaran terapi pasien DM tipe 2 dengan komorbid hipertensi di Rumah Sakit X Pekanbaru.

\section{METODE}

Jenis penelitian ini adalah deskriptif crosssectional yang menggunakan data rekam medis. Populasi penelitian adalah seluruh pasien DM. tipe 2 dengan komorbid hipertensi, di poliklinik Rumah Sakit X Pekanbaru periode januari - desember 2014. Subjek penelitian ini adalah populasi yang memenuhi kriteria yaitu berusia $\geq 18$ tahun, didiagnosis hipertensi atau tekanan darah e" 140/ $90 \mathrm{mmHg}$ atau mendapatkan $\mathrm{OAH}$, data di rekam medis dapat dibaca dan lengkap sesuai kebutuhan penelitian pada kunjungan pertama pada periode penelitian. Sedangkan kriteria eksklusi adalah pasien hamil. Data didapatkan pertamakali dengan cara menelusuri data pasien DM tipe 2 menggunakan komputer di bagian rekam medis yang dikoding berdasarkan ICD 10 dengan kode E 10 - 14. Data yang didapatkan selanjutnya dicatat dalam lembar kerja dan dikumpulkan berdasarkan variabel penelitian, selanjutnya diolah secara manual dan komputerisasi. Hasil penelitian disajikan dalam bentuk tabel dan narasi sesuai dengan tujuan penelitian.

Tabel 1. Karakteristik subjek berdasarkan jenis kelamin, jenis pembiayaan, status pekerjaan, dan tekanan darah

\begin{tabular}{|c|c|c|}
\hline Karakteristik & Jumlah $(n=285)$ & Persentase $(\%)$ \\
\hline \multicolumn{3}{|l|}{ Jenis kelamin } \\
\hline Laki-laki & 110 & 38,6 \\
\hline Perempuan & 175 & 61,4 \\
\hline \multicolumn{3}{|l|}{ Jenis pembiayaan } \\
\hline $\begin{array}{l}\text { Pribadi } \\
\text { BPJS }\end{array}$ & $\begin{array}{c}166 \\
99\end{array}$ & $\begin{array}{l}58,2 \\
34,7\end{array}$ \\
\hline Asuransi lain & 20 & 7 \\
\hline \multicolumn{3}{|l|}{ Status pekerjaan } \\
\hline Tidak bekerja & 114 & 40 \\
\hline Ibu Rumah Tangga (IRT) & 89 & 31,2 \\
\hline Swasta & 51 & 17,9 \\
\hline Pensiunan & 14 & 4,9 \\
\hline Tani & 10 & 3,5 \\
\hline Pegawai Negeri Sipil (PNS) & 7 & 2,5 \\
\hline \multicolumn{3}{|l|}{ Tekanan darah } \\
\hline \multicolumn{3}{|l|}{ Sistolik } \\
\hline$<120$ & 8 & 2,8 \\
\hline $120-139$ & 78 & 27,4 \\
\hline $140-159$ & 88 & 30,9 \\
\hline$\geq 160$ & 111 & 38,9 \\
\hline \multicolumn{3}{|l|}{ Diastolik } \\
\hline$<80$ & 12 & 4,2 \\
\hline $80-89$ & 116 & 40,7 \\
\hline $90-99$ & 74 & 26 \\
\hline$\geq 100$ & 83 & 29,1 \\
\hline
\end{tabular}




\section{HASIL}

Pada penelitian yang telah dilakukan di Rumah Sakit X Pekanbaru didapatkan Populasi pasien DM tipe 2 yang berobat kunjungan pertama di poliklinik Rumah Sakit X Pekanbaru tahun 2014 berjumlah 602 orang, selanjutnya pasien dengan komorbid hipertensi sebanyak 296 orang. Sedangkan 11 rekam medis diantaranya memiliki data yang tidak lengkap sehingga total subjek penelitian ini adalah 285 orang.

\section{Karakteristik Subjek}

Berdasarkan hasil penelitian didapatkan rerata usia pasien DM tipe 2 dengan komorbid hipertensi $57,7( \pm 9,95)$ tahun, termuda 23 tahun dan tertua 86 tahun. Rerata kadar Gula Darah Sewaktu (GDS) $260,7( \pm 126,9) \mathrm{mg} / \mathrm{dL}$, terendah $50 \mathrm{mg} / \mathrm{dL}$ dan tertinggi $586 \mathrm{mg} / \mathrm{dL}$. Jenis kelamin terbanyak perempuan $(61,4 \%)$, jenis pembiayaan terbanyak berurutan pribadi $(58,2 \%)$, Badan Penyelenggara Jaminan Sosial (BPJS) 34,7 \% dan asuransi lain 7\%. Status pekerjaan terbanyak tidak bekerja (40\%) dan ibu rumah tangga $(31,2 \%)$. Subjek terbanyak memiliki tekanan darah sistolik e"160 mmHg $(38,9 \%)$ serta tekanan darah diastolik rentang 80 $89 \mathrm{mmHg}(40,7 \%)$. Karakteristik subjek penelitian lebih rinci dapat dilihat pada tabel 1 .

\section{Gambaran Penggunaan Obat Anti Diabetikum (OAD)}

Pada penelitian ini didapatkan persentase penggunaan $\mathrm{OAD}$ secara berurutan yaitu oral, tanpa OAD, dan insulin $(83,15 \%, 13,33 \%$, dan $3,5 \%)$. Gambaran penggunaan OAD pada pasien DM tipe 2 dengan komorbid hipertensi pada penelitian ini dapat dilihat pada tabel 2 sampai 4.

Tabel 2. Gambaran penggunaan OAD berdasarkan jumlah obat

\begin{tabular}{lcc}
\hline \multicolumn{1}{c}{ Jumlah obat perhari } & Jumlah $(\mathrm{n}=285)$ & Persentase (\%) \\
\hline Tanpa OAD & 38 & 13,3 \\
OAD oral & 237 & 83,15 \\
Tunggal & 85 & 29,82 \\
Kombinasi & 152 & 53,33 \\
Dua & 141 & 49,47 \\
Tiga & 11 & 3,86 \\
OAD injeksi ( insulin) & 10 & 3,5 \\
Tunggal & 4 & 1,5 \\
Kombinasi insulin + OAD oral & 6 & 2,1 \\
\hline
\end{tabular}

Tabel 2 juga menjelaskan bahwa jumlah OAD oral paling banyak digunakan adalah kombinasi dua obat $49,47 \%$ diikuti tunggal $29,82 \%$. Sedangkan insulin digunakan $2,1 \%$ dalam kombinasi OAD oral dan paling sedikit $1,5 \%$ subjek yang menggunakan insulin tunggal.

Berdasarkan tabel 3 didapatkan bahwa penggunaan OAD oral baik secara tunggal atau kombinasi terbanyak adalah, golongan penghambat glukoneogenesis yaitu metformin 90,3\% dengan dosis harian terbanyak $1000-1500 \mathrm{mg}(74,26 \%)$, diikuti pemicu sekresi insulin 69,2\% (terbanyak glimepirid $61,2 \%$ dengan dosis harian terbanyak 1-2 mg $(55,7 \%)$ dan terkecil glikuidon sebesar $1,69 \%$ dengan dosis 30 dan $60 \mathrm{mg}$ ). Paling sedikit penggunaan $\mathrm{OAD}$ oral adalah golongan penghambat alfa glukosidase sebesar 1,69\% dan OAD golongan ini tidak ada digunakan secara tunggal.

Pada tabel 4 didapatkan gambaran penggunaan OAD injeksi (insulin) oleh 10 subjek, terbanyak adalah Premixed insulin (60\%) dengan dosis harian tersering digunakan sebesar 18 IU (20\%). Tidak ada subyek yang menggunakan Rapidacting insulin dan Intermediate-acting insulin. 
Tabel 3. Gambaran penggunaan OAD oral berdasarkan golongan dan dosis harian

\begin{tabular}{|c|c|c|}
\hline Golongan / Jumlah dosis harian (mg) & Jumlah $(n=237)^{*}$ & Persentase (\%) \\
\hline Pemicu sekresi insulin $^{\mathrm{a}}$ & 164 & 69,2 \\
\hline Glimepirid & 145 & 61,2 \\
\hline $1-2$ & 132 & 55,7 \\
\hline 3-4 & 12 & 5,06 \\
\hline$>4$ & 1 & 0,42 \\
\hline Glibenklamid & 15 & 6,32 \\
\hline$\leq 5$ & 12 & 5,06 \\
\hline$>5$ & 3 & 1,27 \\
\hline Glikuidon & 4 & 1,69 \\
\hline 30 & 2 & 0,84 \\
\hline 60 & 2 & 0,84 \\
\hline Penghambat glukoneogenesis (Metformin) & 214 & 90,3 \\
\hline$<1000$ & 15 & 6,32 \\
\hline $1000-1500$ & 176 & 74,26 \\
\hline$>1500$ & 23 & 9,7 \\
\hline Penghambat alfa glukosidase (Acarbose) ${ }^{b}$ & 4 & 1,69 \\
\hline$\leq 150$ & 1 & 0,42 \\
\hline$>150$ & 3 & 1,27 \\
\hline DPP-IV inhibitor (Vidagliptin) ${ }^{\mathrm{a}}$ & 18 & 7,59 \\
\hline 50 & 3 & 1,27 \\
\hline 100 & 15 & 6,32 \\
\hline
\end{tabular}

adigunakan tunggal atau kombinasi, ${ }^{\text {b }}$ digunakan secara kombinasi, ${ }^{*}$ jumlah pengguna OAD oral

Tabel 4. Gambaran penggunaan OAD injeksi berdasarkan golongan dan jumlah dosis harian

\begin{tabular}{lcc}
\hline Golongan / Jumlah dosis harian (IU) & Jumlah $(\mathrm{n}=10)^{*}$ & Persentase (\%) \\
\hline Rapid-acting insulin & 0 & 0 \\
\hline Short-acting insulin & 1 & 10 \\
60 & & \\
& 0 & \\
Intermediate-acting insulin & & \\
& & 30 \\
Long-acting insulin & 3 & 10 \\
10 & 1 & 20 \\
16 & 2 & 60 \\
Premixed insulin & 6 & 20 \\
18 & 2 & 10 \\
20 & 1 & 10 \\
26 & 1 & 10 \\
28 & 1 & 10 \\
34 & 1 & \\
\hline
\end{tabular}

adigunakan tunggal atau kombinasi, ${ }^{*}$ jumlah pengguna OAD injeksi 


\section{Gambaran Penggunaan Obat Anti Hipertensi (OAH)}

Pada penelitian ini didapatkan tidak seluruh pasien DM tipe 2 dengan komorbid hipertensi yang mendapatkan terapi OAH, hampir separuh subjek tanpa OAH $128(44,91 \%)$. Penggunaan $\mathrm{OAH}$ berdasarkan jumlah obat secara berurutan dari yang paling banyak adalah subjek mendapatkan satu OAH 41,75\%, kombinasi dua OAH 11,92\% dan tiga OAH 1,4\% (tabel 5).

Tabel 5. Gambaran penggunaan OAH berdasarkan jumlah

\begin{tabular}{lcc}
\hline Jumlah obat & Jumlah $(\mathrm{n}=285)$ & Persentase (\%) \\
\hline Tanpa OAH & 128 & 44,91 \\
Tunggal & 119 & 41,75 \\
Kombinasi & 38 & 13,33 \\
Dua & 34 & 11,92 \\
Tiga & 4 & 1,4 \\
\hline
\end{tabular}

Tabel 6 menerangkan bahwa jumlah subjek yang mendapatkan OAH adalah 157 orang. Lebih dari separuh subjek tersebut menggunakan $\mathrm{OAH}$ candesartan $(66,24 \%)$ dari golongan antagonis reseptor angiotensin II $(75,8 \%)$, dengan dosis harian yang paling sering digunakan $>8 \mathrm{mg}(49,68 \%)$, sedangkan valsartan hanya 9,55\%. Berikutnya adalah antagonis kalsium (amlodipin) yaitu 35,67\% dengan dosis harian tersering digunakan $10 \mathrm{mg}$ $(19,74 \%)$. Paling sedikit subjek yang menggunakan golongan diuretik tiazid / hidroklortiazid $25 \mathrm{mg}$ sebesar $7 \%$.

Tabel 6. Gambaran penggunaan OAH berdasarkan golongan dan jumlah dosis harian

\begin{tabular}{|c|c|c|}
\hline Golongan/ Jumlah dosis harian (mg) & Jumlah $(\mathrm{n}=157)^{*}$ & Persentase $(\%)$ \\
\hline Diuretik tiazid (Hidroklortiazid) ${ }^{\mathrm{a}} 25$ & 11 & 7 \\
\hline Penghambat angiotensin-converting enzyme $e^{\mathrm{a}}$ & 14 & 8,9 \\
\hline Captopril & 11 & 7 \\
\hline$\leq 25$ & 7 & 4,46 \\
\hline$>25$ & 4 & 2,55 \\
\hline Ramipril 5 & 3 & 1,91 \\
\hline Antagonis reseptor angiotensin II (ARB) ${ }^{\mathrm{a}}$ & 119 & 75,8 \\
\hline Candesartan & 104 & 66,24 \\
\hline$\leq 8$ & 26 & 16,56 \\
\hline$>8$ & 78 & 49,68 \\
\hline Valsartan & 15 & 9,55 \\
\hline 80 & 9 & 5,73 \\
\hline 160 & 6 & 3,82 \\
\hline Antagonis kalsium (amlodipin) ${ }^{\mathrm{a}}$ & 56 & 35,67 \\
\hline 5 & 25 & 15,92 \\
\hline 10 & 31 & 19,74 \\
\hline
\end{tabular}

adigunakan tunggal atau kombinasi, "jumlah pengguna $\mathrm{OAH}$ 


\section{PEMBAHASAN}

\section{Gambaran Penggunaan Obat Anti Diabetikum (OAD)}

Pada penelitian yang dilakukan terhadap 285 subjek pasien DM tipe 2 dengan komorbid hipertensi. Gambaran penggunaan OAD pada penelitian ini didapatkan ada subjek yang tidak menggunakan OAD yaitu $13,3 \%$. Subjek yang tidak menggunakan OAD dapat dikarenakan gula darahnya sudah terkontrol atau dibawah normal, dibuktikan dengan adanya subjek yang memiliki kadar GDS $50 \mathrm{mg} / \mathrm{dL}$. Parameter yang menunjukkan gula darah terkontrol adalah HbA1c $<7 \%$, kadar gula darah puasa $<100 \mathrm{mg} / \mathrm{dL}$, dan gula darah 2 jam setelah makan $<140 \mathrm{mg} / \mathrm{dL} .{ }^{5,7}$

Penatalaksanaan DM tipe 2 dengan komorbid hipertensi pada prinsipnya sama dengan penatalaksanaan DM pada umumnya yang meliputi penatalaksanaan non-farmakologis dan farmakologis. Gaya hidup sehat termasuk pengaturan pola makan, latihan jasmani, penurunan berat badan serta edukasi merupakan penatalaksanaan non-farmakologis yang penting dan tetap harus dilaksanakan walaupun sudah mendapatkan terapi farmakologis. ${ }^{5,7}$

Lebih dari dua pertiga subjek mendapatkan OAD oral $(83,15 \%)$, paling banyak digunakan sebagai kombinasi dua obat $(53,33 \%)$ diikuti tunggal $(29,82 \%)$. Bersamaan dengan terapi nonfarmakologi pertimbangan pemberian OAD pada pasien DM tipe 2 dipengaruhi oleh kadar gula darah, HbA1c, dan ada tidaknya komorbid. Terapi dapat dimulai dari OAD tunggal atau kombinasi sejak dini. ${ }^{5}$ Subjek penelitian ini adalah pasien DM yang memiliki komorbid sehingga perlu lebih agresif dalam pengendalian gula darahnya. Kemungkinan pasien ini juga sudah mengalami hiperglikemia yang menahun sehingga mengalami komplikasi hipertensi, dan kadar gula darahnya tidak terkontrol setelah terapi sebelumnya, sehingga paling banyak diberikan dalam bentuk kombinasi.

Subjek yang digunakan adalah pasien poliklinik di rumah sakit sehingga OAD oral lebih banyak digunakan dibandingkan insulin yang diberikan secara injeksi. Hal ini dapat dikarenakan pasien poliklinik tidak memerlukan menurunan gula darah segera seperti DM dengan komplikasi akut yang dirawat inap. Namun indikasi pemberian insulin juga terhadap pasien rawat jalan yang gagal dengan kombinasi OAD dosis optimal, gangguan fungsi hati dan ginjal yang berat, kontra indikasi OAD dan alergi OAD ${ }^{5,7}$ Hasil ini senada dengan penelitian RS Mumbai India pada 100 pasien DM tipe 2 yang sebagian besar $(56,4 \%)$ mendapatkan terapi OAD dibanding insulin $(43,6 \%)$, namum pada penelitian ini terapi tunggal OAD lebih banyak digunakan dibandingkan kombinasi. ${ }^{8}$

Penelitian ini juga mendapatkan hasil OAD oral terbanyak digunakan sebagai terapi adalah metformin (90,3\%), diikuti oleh golongan pemicu sekresi insulin yaitu sulfonilurea. Metformin merupakan OAD dari golongan penghambat glukoneogenesis. Efek utama obat golongan penghambat glukoneogenesis adalah mengurangi produksi glukosa hati dan memperbaiki ambilan glukosa perifer. Golongan penghambat glukoneogenesis dapat memperbaiki ambilan glukosa sebesar 10-40\%, mengurangi glikogenolisis dan glukoneogenesis sehingga dapat menurunkan kadar glukosa hati. ${ }^{3,8} \mathrm{Hal}$ ini berbeda dengan penelitian Mumbai india didapatkan penggunaan golongan penghambat glukoneogenesis di rumah sakit urutan kedua setelah sulfonilurea. ${ }^{8}$

Dosis harian metformin tersering digunakan pada penelitian ini adalah $1000-1500 \mathrm{mg}$. Penggunaan metformin dimulai dari dosis $500 \mathrm{mg}$ $2 \mathrm{x} /$ hari atau $850 \mathrm{mg} 1 \mathrm{x} /$ hari. Penambahan dosis harus dilakukan secara bertahap dapat dilakukan penambahan dosis $500 \mathrm{mg}$ setelah 1 minggu pertama pengobatan atau ditambahkan $850 \mathrm{mg}$ setelah 2 minggu pengobatan apabila tidak terjadi respon pengobatan sebelumnya. ${ }^{7,9}$

Pada penelitian ini penggunaan OAD injeksi tersering adalah premixed insulin (60\%) dengan dosis harian tersering adalah $18 \mathrm{IU}$ (20\%). Penelitian ini tidak sejalan dengan penelitian Soewondo di RSCM didapatkan penggunaan terbanyak adalah short-acting insulin (34\%). ${ }^{10}$ Penelitian lain yang dilakukan Yulianti dkk di Palu didapatkan jenis rapid-acting insulin yaitu novorapid $(35,29 \%) .{ }^{11}$ Premixed insulin terdiri dari short-acting insulin dan intermediate-acting insulin. Premixed insulin dibuat untuk memenuhi kebutuhan insulin setiap harinya dan digunakan 2x sehari sebelum sarapan pagi dan sebelum makan malam. ${ }^{12}$ Pemberian dosis harian 
insulin tergantung kadar gula darah dan pada umumnya sama untuk semua jenis insulin. Berdasarkan ATC/DD (Anatomical Therapeutic Chemical/Defined Daily Dose) WHO tahun 2015 dosis harian untuk insulin adalah 40 IU perhari. ${ }^{13}$ Sedangkan dosis penggunaan insulin berdasarkan konsensus PERKENI adalah dosis untuk shortacting insulin dan rapid-acting insulin $0,1 \mathrm{IU} / \mathrm{kgBB}$ setiap kali makan, dosis untuk long-acting insulin $10 \mathrm{IU}$ sebelum tidur. ${ }^{5}$ Dosis penggunaan insulin ini sudah sesuai dengan konsensus PERKENI.

\section{Gambaran Penggunaan Obat Anti Hipertensi (OAH)}

Hasil penelitian ini juga menggambarkan lebih dari separuh subjek memiliki tekanan darah sistolik $>130 \mathrm{mmHg}$ dan lebih dari dua pertiganya memiliki diastolik > $80 \mathrm{mmHg}$. Namun masih banyak pasien DM tipe 2 dengan komorbid hipertensi yang tidak mendapatkan terapi OAH $(44,91 \%)$. Hal ini belum sesuai dengan konsensus Perhimpunan Endokrinologi Indonesia (PERKENI) tahun 2011 bahwa indikasi pengobatan hipertensi pada DM tipe 2 adalah apabila tekanan darah sistolik $>130 \mathrm{mmHg}$ dan atau tekanan darah diastolik $>80 \mathrm{mmHg} .{ }^{5}$

Subjek yang diikutkan pada penelitian ini adalah yang memiliki data yang lengkap pada kunjungan pertama, sehingga mungkin dokter baru pertama mendiagnosis komorbid hipertensi. Hal tersebut dapat menjadi pertimbangan dokter untuk tidak langsung memberikan terapi OAH karena penatalaksanaan pasien DM tipe 2 dengan komorbid hipertensi juga dimulai dengan modifikasi gaya hidup. Pengaturan tekanan darah dan inisiasi farmakoterapi menurut Joint National Committee (JNC VIII) tahun 2013 berdasarkan umur, adanya penyakit DM dan Chronic Kidney Disease (CKD). ${ }^{6}$

Hasil penelitian ini didapatkan penggunaan OAH terbanyak tunggal $(41,75 \%)$ dan golongan antagonis reseptor angiotensin II (75,8\%). Candesartan dan valsartan dari golongan antagonis reseptor angiotensin II yang digunakan pada penelitian ini, terbanyak adalah candesartan $(66,24 \%)$ dengan dosis harian terbanyak adalah $>8$ $\mathrm{mg}$. Antagonis reseptor angiotensin II terutama terdapat pada otot polos pembuluh darah dan jantung, hal ini lah yang disinyalir memperantarai semua efek angiotensin II yang terutama berperan dalam homeostasis kardiovaskular sehingga dapat memperbaiki keadaan pasien. ${ }^{6}$

Penelitian ini sesuai dengan rekomendasi JNC VIII bahwa inisiasi pengobatan hipertensi dengan DM non kulit hitam adalah thiazid/ ACE-inhibitor/ Antagonis reseptor angiotensin II/antagonis kalsium. diberikan tunggal atau kombinasi. Target tekanan darah sistolik < $140 \mathrm{mmHg}$ dan diastolik < $90 \mathrm{mmHg}$. Target tersebut dapat dicapai dengan cara meningkatkan dosis obat atau menambahkan obat kedua atau mulai dengan dua golongan obat. ${ }^{6}$ Hasil penelitian yang sama didapatkan bahwa $\mathrm{OAH}$ tunggal paling banyak digunakan pada pasien DM tipe 2 di Instalasi Rawat inap BLU RSUP Prof. R. D. Kandou Manado terdiri dari terapi tunggal $(53,66 \%)$, sedangkan penggunaan antihipertensi terbanyak adalah golongan $A C E$-Inhibitor $(31,82 \%)$ yaitu captopril $(27,27 \%) .{ }^{14}$

Pemberian candesartan akan mengakibatkan penghambatan semua efek angitotensin II. Obat ini memiliki efek yang hampir sama dengan ACE-I tetapi memiliki keunggulan tidak menimbulkan efek samping batuk kering dan angioedema. ${ }^{6}$ Namun harga OAH golongan Antagonis reseptor angiotensin II relatif lebih mahal dari ACE-I.

\section{KESIMPULAN}

Terapi OAD yang diberikan pada pasien DM tipe 2 dengan komorbid hipertensi sebagian besar adalah OAD oral $(83,15 \%)$. Berdasarkan total subjek yang mendapatkan OAD oral, mayoritas mendapatkan OAD kombinasi dua obat $(53,33 \%)$, golongan peng penghambat glukoneogenesis yaitu metformin (90,3\%) dengan dosis harian tersering digunakan 1000 - $1500 \mathrm{mg}$ (74,26\%). Sedangkan dari 10 subjek yang mendapatkan OAD injeksi, terbanyak adalah adalah Premixed insulin $(60 \%)$ dengan dosis harian tersering digunakan sebesar 18 IU (20\%). Terapi OAH yang diberikan pada subjek penelitian ini mayoritas OAH tunggal $(41,75 \%)$, namun masih ada subjek yang tidak mendapatkan OAH $(44,91 \%)$. Berdasarkan total subjek yang mendapatkan $\mathrm{OAH}$, candesartan paling banyak digunakan $(66,24 \%)$ dengan dosis harian yang paling sering digunakan adalah $>8 \mathrm{mg}(49,68 \%)$. 


\section{DAFTAR PUSTAKA}

1. Kementerian Kesehatan Republik Indonesia. Pedoman dan pengendalian diabetes melitus dan penyakit metabolik. Dep Kes RI.2008

2. Kementerian Kesehatan Republik Indonesia. Diabetes melitus penyebab kematian nomor 6 di dunia : Kemenkes Tawarkan Solusi CERDIK melalui POSBINDU. [ serial on internet]. [cited 2015 jan 10]. Available from : http:// www.depkes.go.id/article/view/diabetesmelitus-penyebab-kematian-nomor-6-di-duniakemenkes-tawarkan-solusi-cerdik-melaluiposbindu.html

3. Showers JR, Murray Epstein. Diabetes mellitus and associated hypertension, vascular disease, and nephropathy. Hypertension. 1995;26:869-79. [cited 2015 March 12]. Available from : http:// hyper.ahajournals.org/content/26/6/869.full

4. Mengesha AY. Hypertension and related riks factors in type 2 diabetes mellitus (DM) patients in Gaborone City (GCC) clinics, Gaborone,Botswana. African Health Sciences. 2007 Des;7.[cited 2015 march 10]. Available from : http://www.ncbi.nlm.nih.gov/pmc/ articles/PMC3074377/pdf/AFHS0704-0244.pdf

5. Perkumpulan Endokrinologi Indonesia (PERKENI). Konsensus pengelolaan dan pencegahan diabetes melitus Tipe 2 di Indonesia.2011

6. James PA, Oparil S, Carter BL, et al. 2014 evidence-based guideline for the management of high blood pressure in adults : report from the panel members appointed to the Eighth Joint National Committee (JNC 8). JAMA. doi : 10.1001/JAMA.2013.284427
7. Nathan DM, Buse JB, Davidson MB, Ferrannini E, Holman RR, Sherwin R et al. Medical management of hyperglycemia in type 2 diabetes : consensus algorithm for initiation and adjustment of therapy. Diabetes care. 2009;32(1):193-203.

8. Agarwal AA, Jadhav PR, Deshmukh YA. Prescribing pattern and efficacy of anti diabetic drugs in maintaining optimal glycemic levels in diabetic patients. Journal of Basic and Clinical Pharmacy. 2014 ; 5(3):79-83

9. Dipiro J. Talbert RL. Yee GC. Matzke GR. Wells BG. Posey LM. Pharmacotherapy: a pathophysiologic approach. 7th ed. New York: Editora McGraw-Hill; 2009. p. 2581

10. Soewondo P, Subekti I. Glycemic control in switching insulin-based regimen among type 2 diabetic patients. Indon med assoc; 2011

11. Yulianti SR, Mukaddas A, Faustine I. Profil pengobatan pasien diabetes melitus tipe 2 di instalasi rawat inap RSUD undata palu tahun 2012. Online jurnal of natural science. 2014; $3: 43$

12. Garber, A J. Premixed insulin analogues for the treatment of diabetes mellitus. Springer Link. 2006; $66: 31-49$

13. World Health Organization (WHO). Guidelines for ATC classification and DDD assignment. Edisi 18. Oslo; 2015

14.Ansa, D A. Lily R G. Heedy M T. Kajian penggunaan obat anti hipertensi pada pasien diabetes melitus tipe 2 di Instalasi rawat inap BLU RSUP Prof.dr.R.D. Kandou Manado periode Januari-Desember 2010.[Skripsi]. Fakultas Matematika dan Ilmu Pengetahuan Alam Universitas Sam Ratulangi Manado. 2010. 